BJHS 53(3): 351-369, September 2020. C The Author(s), 2020. Published by Cambridge University Press on behalf of British Society for the History of Science. This is an Open Access article, distributed under the terms of the Creative Commons Attribution licence (http:// creativecommons.org/licenses/by/4.0/), which permits unrestricted re-use, distribution, and reproduction in any medium, provided the original work is properly cited.

doi:10.1017/S0007087420000242 First published online 16 July 2020

\title{
The logistics of the Republic of Letters: mercantile undercurrents of early modern scholarly knowledge circulation
}

\author{
JACOB ORRJE"
}

\begin{abstract}
Anglo-Swedish scholarly correspondence from the mid-eighteenth century contains repeated mentions of two merchants, Abraham Spalding and Gustavus Brander. The letters describe how these men facilitated the exchange of knowledge over the Baltic Sea and the North Sea by shipping letters, books and other scientific objects, as well as by enabling longdistance financial transactions. Through the case of Spalding and Brander, this article examines the material basis for early modern scholarly exchange. Using the concept of logistics to highlight and relate several mercantile practices, it examines ways of making scholarly knowledge move, and analyses merchants' potential motives for offering their services to scholarly communities. As logisticians in the Republic of Letters, these merchants could turn their commercial infrastructure into a generator of cultural status valid in both London and Stockholm. Using mercantile services, scholarly knowledge could in turn traverse the region in reliable, costeffective and secure ways. The case of Spalding and Brander thus highlights how contacts between scholarly communities intersected with other contemporary modes of transnational exchange, and it shows how scholarly exchange relied on relationships based on norms different from the communalism often used to characterize the early modern Republic of Letters. Thus the article suggests new ways of studying early modern scholarly exchange in practice.
\end{abstract}

In the evening at sunset we arrived at London. Immediately upon my arrival I addressed myself, according to the instructions given me by the Royal Academy of Science of Sweden, to Mr. Abraham Spalding, a Swedish merchant in London, who afterwards, during the whole of my visit to England gave me every imaginable information, help, advice, and explanation of various things; recommended me, partly himself, partly through his friends, to all the places I had occasion to visit, or where there was anything remarkable to see; lent me all the money I required for the whole of my foreign travels, and besides that, showed me manifold kindness. ${ }^{1}$

In Anglo-Swedish learned correspondence from the mid-eighteenth century, as well as in travelogues by Swedish visitors to England of the same period, one can often read

* Uppsala University, Department for History of Science and Ideas, Box 629, 75126 Uppsala, Sweden. Email: jacob.orrje@idehist.uu.se.

I would like to thank Hjalmar Fors, Linn Holmberg, Amanda Rees and the reviewers for their help and comments on this paper. Early versions were presented at the History of Ideas seminar at Stockholm University, and the seminar for History of Science and Technology at Chalmers University of Technology in Gothenburg. I am grateful to the participants of these seminars for their helpful comments. This study was supported by the Swedish Research Council (Ref: 2017-02271).

1 Pehr Kalm, Kalm's Account of His Visit to England on His Way to America in 1748 (tr. Joseph Lucas), London: Macmillan and Co., 1892, p. 6. 
about the two London merchants Abraham Spalding and Gustavus Brander. Generally, scholars described how they facilitated the movement of scholarly knowledge; they introduced scholars to London, enabled letter correspondents to communicate, shipped instruments and helped with money transfers. In this paper, I put these two merchants in the limelight. While traditional history of science might view actors such as these as peripheral, I argue that merchants were central to making eighteenth-century knowledge move.

How did the early modern Republic of Letters exchange knowledge? During the 1990s and early 2000s, this question generated several studies among cultural historians and historians of science. Instead of examining what was communicated, these studies put the communication itself and its social practices in focus. As, for example, argued by Anne Goldgar, the Republic of Letters 'was a community of obligation', where status was beneficent rather than economic. Goldgar thus described early modern scholarly communication as constituted by the mutual assistance between members. ${ }^{2}$ These earlier studies nevertheless paid little attention to the material aspects of early modern transnational communication, such as how letters, books or scholars moved across the continent in practice. Neither did they focus much on the categories of actors who managed the flow of these objects - such as merchants, shippers and postal workers nor on the motives such actors might have had for participating in the exchange of scholarly knowledge. By focusing on merchants' participation in the Republic of Letters, it is thus possible to understand letter correspondence in a larger context of study tours, shipments of instruments and financial transactions. ${ }^{3}$

More recently, global historians have stressed the role of intermediary actors in making knowledge move. By focusing on go-betweens with the ability to move and translate between disparate cultures of knowledge, these studies have shown how knowledge circulated between many cultures, spread over diverse geographies. ${ }^{4}$ Moreover, new studies by postal historians have shown how early modern correspondence was

2 Anne Goldgar, Impolite Learning: Conduct and Community in the Republic of Letters, 1680-1750, New Haven, CT: Yale University Press, 1995, pp. 13, 28, 26. Similar points about the sociability of the Republic of Letters can be found in Lorraine Daston, 'Nationalism and scientific neutrality under Napoleon', in Tore Frängsmyr (ed.), Solomon's House Revisited: The Organization and Institutionalization of Science, Canton, MA: Science History Publications, 1990, pp. 95-115; Daston, 'The ideal and reality of the Republic of Letters in the Enlightenment', Science in Context (1991) 4(2), pp. 367-386; Dena Goodman, The Republic of Letters: A Cultural History of the French Enlightenment, Ithaca, NY: Cornell University Press, 1994. Following in the wake of Goodman, feminist studies have discussed the boundaries of this sociability; see e.g. Susan Dalton, Engendering the Republic of Letters: Reconnecting Public and Private Spheres in Eighteenth-Century Europe, Montreal: McGill-Queen's University Press, 2003; Carol Pal, Republic of Women: Rethinking the Republic of Letters in the Seventeenth Century, Cambridge: Cambridge University Press, 2012.

3 The benefits of such a broader approach of linking scholarly activity to contemporary global systems of trade and information exchange can be seen in Simon Schaffer, 'Newton on the beach: the information order of Principia Mathematica', History of Science (2009) 47(3), pp. 243-276.

4 For an overview of intermediaries and go-betweens in the history of science see Kapil Raj, 'Gobetweens, travelers, and cultural translators', in Bernard Lightman (ed.), A Companion to the History of Science, Chichester: John Wiley \& Sons, 2016, pp. 39-57. On circulation of knowledge see James A. Secord, 'Knowledge in transit', Isis (2004) 95(4), pp. 654-672; Kapil Raj, 'Introduction: circulation and locality in early modern science', BJHS (2010) 43(4), pp. 513-517. Though Goldgar has written about intermediaries in the Republic of Letters, she does so exclusively in the context of scholars 
made possible by a communication infrastructure, consisting of diverse categories of actors such as merchants, shippers and postmasters. ${ }^{5}$ All in all, these studies have underlined how scholarly communication must be seen as intersected with other modes of transnational exchange.

Here, I approach the material basis for early modern scholarly knowledge exchange through the broader concept of logistics. The modern notion of logistics certainly would have been foreign to the eighteenth-century actors studied here. Logistics as a concept was first defined by Baron de Jomini in 1830 as 'the art of well ordering the movements of an army, of well combining the order of troops in columns, the time of their departure, their itinerary, the methods of communication necessary to assure their arrival at a decided place'. 6 It was not until the twentieth century that logistics became a field of non-military knowledge, mainly in business and engineering, that concerned 'the efficient transfer of goods from the source of supply through the place of manufacture to the point of consumption in a cost-effective way'. ${ }^{7}$ However, as I discuss in more detail in the ensuing sections, the expertise of managing the flow of goods and information was central to both merchants' business endeavours and the transnational circulation of early modern scholarly knowledge. As an analytic concept, logistics thus highlights how mercantile practices, which were the basis for early modern long-distance trade, were pivotal for transnational exchange of scholarly knowledge. 8

After giving a brief biographical account of Spalding and Brander, I explore three sets of questions. First, what motivated these merchants to participate in Anglo-Swedish scholarly exchange? How can we understand their motivations in relation to the cultures in which they lived? Second, what logistical services did merchants provide to early modern scholars, and how did such services relate to contemporary mercantile practices of long-distance shipping and financing? And finally, how did these services facilitate the knowledge circulation among transnational communities of scholars? By answering

employing other scholars (or in some cases a bookseller), as middlemen in order to establish new contacts. See Goldgar, op. cit. (2), pp. 30-32.

5 Jay Caplan, Postal Culture in Europe, 1500-1800, Oxford: Voltaire Foundation, 2016, pp. 1-3. See also Susan E. Whyman, The Pen and the People: English Letter Writers 1660-1800, Oxford: Oxford University Press, 2009, pp. 3-18. In-depth analyses of the postal system in the Baltic region, albeit mainly during a somewhat earlier period, can be found in Magnus Linnarsson, Postgång på växlande villkor: det svenska postväsendets organisation under stormaktstiden, Lund: Nordic Academic Press, 2010; Heiko Droste, Connecting the Baltic Area: The Swedish Postal System in the Seventeenth Century, Huddinge: Södertörn University, 2011.

6 Antoine-Henri de Jomini, Tableau analytique des principales combinaisons de la guerre et de leurs rapports avec la politique des états, pour servir d'introduction au 'Traité des grandes opérations militaires', Paris: Anselin, 1830, p. 74: 'l'art de bien ordonner les marches d'une armée, de bien combiner l'ordre des troupes dans les colonnes, le tems de leur départ, leur itinéraire, les moyens de communications nécessaires pour assurer leur arrivée à point nommé'.

7 Peter Baker, Phil Croucher and Alan Rushton, The Handbook of Logistics and Distribution Management: Understanding the Supply Chain, London: Kogan Page Publishers, 2017, p. 6.

8 For other ways in which scholarly and mercantile practices intersected in early modern Europe, e.g. in the book trade, see Dániel Margócsy, Commercial Visions: Science, Trade, and Visual Culture in the Dutch Golden Age, Chicago: The University of Chicago Press, 2014. 
these questions, the paper aims to show the importance of mercantile practices in the early modern exchange of scholarly knowledge and to propose that we should adopt a broader view of the relationships that constituted the Republic of Letters.

\section{Two merchants in the Anglo-Swedish iron trade}

From sometime in the late 1740 s or early 1750s, Abraham Spalding and Gustavus Brander were in a private partnership. That is, they had agreed on a voluntary contract to merge resources such as money, goods, labour and knowledge. Moreover, they had agreed to share profits or losses proportionally. Spalding and Brander's partnership was in many ways typical of the private collaborations found among the merchants of eighteenth-century London: they generally tended to be small, involving no more than two or three merchants. Moreover, kinship was often a basis for such relationships. ${ }^{9}$

It is unsurprising, then, that Spalding and Brander were cousins. Gustavus Brander was born in London (2 March 1721), the second son of the merchant Charles Brander (1683-1745) and Margareta Katarina Spicker (born 1688). The father was a merchant in the Anglo-Swedish metal trade who had moved to London from Stockholm at the beginning of the century, and who was naturalized in 1705. After his father died in 1745, Gustavus inherited the family business. Abraham Spalding (1712-1782), on the other hand, grew up in Stockholm. He was the son of Anna Kristina Brander (1684-1757), Gustavus's aunt, and Johan Spalding, a wealthy textile trader from Stockholm (1669-1738). The Spalding family was of Scottish origin, but from the seventeenth century it had spread to places throughout the Baltic and North Sea region, involving both Mecklenburg and several towns in Sweden. Soon after his father's death, Abraham moved to London. ${ }^{10}$

The two cousins traded together from sometime in the late 1740 s or early 1750 s. From the early 1760s, they shared a house by the small square White Lyon Court just by the Royal Exchange. ${ }^{11}$ At this time, London was an increasingly important node in a global system of the metal trade, as well as a big consumer of naval supplies. Large quantities of these goods were produced around the Baltic Sea, and the two merchants thus

9 David Hancock, Citizens of the World: London Merchants and the Integration of the British Atlantic Community, 1735-1785, Cambridge: Cambridge University Press, 1995, pp. 104-107.

10 'Baptism record of Anna Kristina Brander', 1685, Births and Baptisms, main series, C I a 1/4 (16701687), Archive of Storkyrkoförsamlingen, Stockholm City Archive (SSA). The ODNB incorrectly states Gustavus's year of birth as 1719-1720; the correct date, 2 March 1721, can be found in the baptism records of the Swedish Lutheran Church in London: Ulrika Eleanora församling, C1, Archive of the Church of Sweden, Uppsala, p. 7. 'Baptism record of Abraham Spalding', 1712, Births and Baptisms, main series, C I a 1/6, Archive of Storkyrkoförsamlingen, SSA; Klas Nyberg, 'Merchants settlements as intermediaries for European influences in the Baltic North 1650-1850, or elsewhere', Helsinki, IEHC Congress, 2006, p. 11. For a general overview of the transnational family of the Spaldings see Eduard Spalding, Geschichtliches, Urkunden, Stammtafeln der Spalding in Schottland, Deutschland und Schweden während der letzten sechs Jahrhunderte, speciell der deutsche Zweig der Familie, Gloedenhof, Greifswald, 1898.

11 The location of Spalding and Brander's house can be seen in 'A plan of the great fire in Bishopsgate Street, Leadenhall Street \& Cornhill \&c. On Thursday Novr 7th 1765', Gentleman's Magazine, London, 1765, opposite p. 533. It was common for merchants in private partnership to live together. For a general discussion of the dwellings of eighteenth-century London merchants see Hancock, op. cit. (9), pp. 85-114. 
participated in the expanding exchange of metals and naval supplies over the Baltic Sea and the North Sea, as well as in Swedish textile imports from the British Isles. Their work involved buying Swedish iron from exporters in Stockholm and Gothenburg and selling it for a profit to British markets. This trade required Spalding and Brander to keep themselves abreast of commercial developments by maintaining relationships with trusted and reliable partners in the region. Moreover, to be successful they needed to control the shipping of large quantities of heavy goods over the North Sea and the Baltic Sea by building relationships with trusted shippers. And finally, they also established contacts with credible financial counterparties, used in long-distance monetary transactions. $^{12}$ All in all, their business thus required a logistical infrastructure, through which the merchants could manage the flow of money, information and goods in the Northern European metal trade. As seen in the following, this infrastructure was also used by contemporary scholars in the region.

\section{Transnational cultures of public science}

In many ways, the role of useful knowledge in Swedish culture of this time can be seen as a cross-fertilization of a German cameralist ideology, where useful knowledge was closely linked to the state apparatus, and the displays of science found in British lecture halls, coffee shops and magazines, which historians of science have termed 'public science'. ${ }^{13}$ The Royal Swedish Academy of Sciences was founded in 1739. In accordance with the cameralist ideology that permeated the Swedish state apparatus of the time, the academy became geared towards what was called nyttiga wettenskaper; that is, useful knowledge or sciences, such as practical mathematics, economy, natural history and chemistry. Influential social groups in Stockholm came to see useful sciences and arts as the key to improving the state's struggling economy after the fall of its Baltic empire in the aftermath of the Great Northern War. ${ }^{14}$ The academy therefore not only attracted scholars; it also consisted of public servants, the clergy, industrialists and merchants. ${ }^{15}$ In a culture where useful knowledge was increasingly seen as a public good,

12 On the metal trade see Karl-Gustaf Hildebrand, Swedish Iron in the Seventeenth and Eighteenth Centuries: Export Industry before the Industrialization (tr. Paul Britten Austin), Stockholm: Jernkontoret, 1992; Chris Evans and Göran Rydén, Baltic Iron in the Atlantic World in the Eighteenth Century, Leiden: Brill, 2007. Their role in textile imports can be deduced from the main activities of Appelroot and Spalding. See Nyberg, op. cit. (10), p. 11.

13 For a discussion of British eighteenth-century public science see Larry R. Stewart, Rise of Public Science: Rhetoric, Technology and Natural Philosophy in Newtonian Britain, 1660-1750, Cambridge: Cambridge University Press, 1992; Larry Stewart and Paul Weindling, 'Philosophical threads: natural philosophy and public experiment among the weavers of Spitalfields', BJHS (1995) 28(1), pp. 37-62.

14 Karin Johannisson, 'Naturvetenskap på reträtt: en diskussion om naturvetenskapens status under svenskt 1700-tal', Lychnos, 1979, pp. 107-154, 111; Sven Widmalm, 'Instituting science in Sweden', in Roy Porter and Mikuláš Teich (eds.), The Scientific Revolution in National Context, Cambridge: Cambridge University Press, 1992, pp. 240-262, 248-249; Leif Runefelt, Dygden som välståndets grund: dygd, nytta och egennytta $i$ frihetstidens ekonomiska tänkande, Stockholm: Stockholm University, 2005, pp. 33-35.

15 Sten Lindroth, Kungl. svenska vetenskapsakademiens historia 1739-1818, vol. 1, 1, Stockholm: Royal Swedish Academy of Sciences, 1967, pp. 27-30; Patrik Winton, Frihetstidens politiska praktik: nätverk och 
participation in these fields became a way to present oneself as a virtuous member of society, as someone who did not act out of self-interest but for the good of the state. ${ }^{16}$

In the same period, the streets of London were filled with various forums where useful knowledge was displayed, discussed, and made, such as lectures, clubs and societies, as well as a bustling commerce of books and scientific instruments. ${ }^{17}$ From the second half of the seventeenth century, the examination of nature through natural history and experimental philosophy also came to be intimately linked to the British state and its imperial project. ${ }^{18}$ In England, the scientific practitioner was still to a large degree expected to be a gentleman. Over the century, such a gentleman was increasingly expected to engage not only with 'state statistics but information about the population, the economy and society at large'. ${ }^{19}$ Similar to contemporary Sweden, the application of mathematics to useful knowledge came to be considered 'an exemplary mode of reasoning applicable to the analysis and understanding of all sorts of human endeavour'. ${ }^{20}$ In this culture, engaging with fields of knowledge deemed useful, and partaking in economic and scientific societies, was expected of an affluent merchant. ${ }^{21}$

These regional cultures of public science are an important context for understanding merchants' motives for offering their services to scholarly communities. Previous studies have, however, generally analysed public science in a national context. Such a national delimitation is partly understandable, given the fact that early modern Europeans themselves interpreted the virtuous and public-spirited subject in relation to the state of which it was subject. For them, the essence of this virtuous subject was to act in the interest of the publicum (i.e. the king, the parliament or the state apparatus), and the performances involved in such displays varied along with the diverse cultures and political systems of the region. However, it is also evident that a core component of this ideal - i.e. that a virtuous subject was selfless - permeated cultures across the North Sea and the Baltic Sea. ${ }^{22}$

The knowledge that early moderns perceived as useful certainly did not stop at state borders either. In fact, European states made great efforts to acquire foreign knowledge

offentlighet 1746-1766, Uppsala: Acta Universitatis Upsaliensis, 2006, pp. 77-79. On how the status of useful sciences declined by the end of the century see Johannisson, op. cit. (14).

16 Jacob Orrje, Mechanicus: Performing an Early Modern Persona, Uppsala: Acta Universitatis Upsaliensis, 2015, pp. 31-36, 158-198.

17 On public lectures see Simon Schaffer, 'Natural philosophy and public spectacle in the eighteenth century', History of Science (1983) 21, pp. 1-43. For a discussion of the instrument business in relation to lectures and other forms of public science see Jim Bennett, 'Shopping for instruments in Paris and London', in Pamela Smith and Paula Findlen (eds.), Merchants and Marvels: Commerce, Science, and Art in Early Modern Europe, New York and London, 2002, pp. 370-395, 377.

18 John Brewer, The Sinews of Power: War, Money and the English State, 1688-1783, London: Unwin Hyman, 1989, pp. 16-18.

19 Brewer, op. cit. (18), p. 227.

20 Brewer, op. cit. (18), p. 229.

21 Hancock, op. cit. (9), pp. 32-36.

22 Compare, e.g., Steven Shapin, A Social History of Truth: Civility and Science in Seventeenth-Century England, Chicago: The University of Chicago Press, 1994, pp. 83, 224-227; Runefelt, op. cit. (14), pp. 160-161, 172; Andre Wakefield, The Disordered Police State: German Cameralism as Science and Practice, Chicago: The University of Chicago Press, 2009, pp. 7, 90-91; Orrje, op. cit. (16), pp. 28-31, 200-201. 
pertinent to trade, industry and the military. ${ }^{23}$ During the eighteenth century, Britain became an increasingly common destination for study tours of young Swedish students and civil servants, and especially so for those active in mathematical sciences, natural history and œconomy. ${ }^{24}$ Britain was often projected as an ideal from which the Swedish public could learn, and the Swedish state, while employing varying degrees of secrecy, sent observers to British manufactories and naval installations. ${ }^{25}$ From the seventeenth century, Sweden conversely emerged as a centre for linguistic and historical research on the region's Gothic past, a field which engaged a number of British scholars who wished to interpret English history in a broader Northern European context. ${ }^{26}$ Likewise, towards the mid-eighteenth century, Swedish naturalists, and most prominently Carl Linnaeus, were central to fields deemed integral to the colonial enterprises of European states, including British imperial aspirations. ${ }^{27}$ Thus, while the circulation of knowledge between the two states should not be seen as symmetrical in a strict sense-geopolitically Britain was a global power and the Swedish post-empire had just lost its status as a regional power - it should not be seen as unidirectional either. Moreover, the exchanges between the two countries were not simply bilateral, but part of processes of circulation all over the Baltic Sea and North Sea region, as well as globally. ${ }^{28}$

As pointed out above, maintaining transnational relationships was critical to the success of early modern merchants who acted on a regional or a global scale. ${ }^{29}$ To sustain these contacts, merchants who acted in multiple states and who belonged to transnational families needed to relate to diverse local expectations of how a merchant should act. Consequently, Spalding and Brander bore many resemblances to the London merchants active in the colonial trade, who, in Hancock's words, were social amalgams in the sense that their lives and careers combined 'two or three distinct experiences and

23 On eighteenth-century 'industrial espionage' see John Harris, Industrial Espionage and Technology Transfer: Britain and France in the Eighteenth Century, Aldershot: Ashgate, 1998. On 'industrial espionage' as a problematic concept in eighteenth-century studies see Paola Bertucci, 'Enlightened secrets: silk, intelligent travel, and industrial espionage in eighteenth-century France', Technology and Culture (2013) 54 (4), pp. 820-852, 825. On the general movement of technical knowledge in early modern Europe see Liliane Hilaire-Pérez, 'Dissemination of technical knowledge in the Middle Ages and the early modern era: new approaches and methodological issues', Technology and Culture (2006) 47(3), pp. 536-565.

24 For an overview of Swedish eighteenth-century study tours to England see Sven Rydberg, Svenska studieresor till England under Fribetstiden, Uppsala: Almqvist \& Wiksell, 1951.

25 On the Royal Society as a model for the Royal Swedish Academy of Sciences see Lindroth, op. cit. (15), p. 4. On Swedish observers of manufactories in eighteenth-century Britain see A.P. Woolrich, Mechanical Arts o Merchandise: Industrial Espionage and Travellers' Accounts as a Source for Technology Historians, Eindhoven: Archeologische Pers, 1989.

26 Colin Kidd, British Identities before Nationalism: Ethnicity and Nationhood in the Atlantic World, 1600-1800, Cambridge: Cambridge University Press, 1999, p. 221.

27 The role of Swedish natural history in the European colonial enterprise is discussed in Sverker Sörlin, 'Ordering the world for Europe: science as intelligence and information as seen from the northern periphery', Osiris (2000) 15, pp. 51-69.

28 The shift in Sweden's geopolitical status after the 1720s is, for example, evident in the negotiations at the end of the Great Northern War, where France and Britain played a large part. See Michael Roberts, The Age of Liberty: Sweden 1719-1772, Cambridge: Cambridge University Press, 1986, pp. 9-12.

29 Hancock, op. cit. (9), p. 139. 
traditions'.$^{30}$ It is through this context - of multiple loyalties and the need for numerous transnational and heterogeneous relationships - together with the previously discussed cultures of public science, that we can understand why Spalding and Brander offered their logistical services to British and Swedish scholars.

Brander and Spalding participated in Northern European cultures of public science well before they went into partnership. From the 1740s, they subscribed to books, printed in London, on a range of subjects: from typography, religion and literature to practical commercial matters. ${ }^{31}$ During this time, Brander also established himself as a key figure in London's scientific societies. The Society of Antiquarians elected him a fellow on 8 March 1749, and in 1753 he also became a fellow of the Royal Society. The letter documenting his election to the latter society described him as a merchant and gentleman, who was 'well vers'd in Natural History and Several other parts of polite Literature'. ${ }^{32}$ Moreover, on 22 March 1754, he was one of the eleven founders of the Royal Society for the Encouragement of Arts and Manufacture at its first meeting at Rawthmell's coffee house. ${ }^{33}$ Later, he also became a director of the Bank of England (1761-1779) and a trustee of the British Museum (1761). ${ }^{34}$

Gustavus Brander visited Stockholm in 1751. By visiting Sweden, he could acquaint himself with a country that he possibly had never visited before, but which was central for both his family and his business practice. There, Brander could reinforce relationships with his suppliers, and develop Swedish language skills. His visit was, however, also an opportunity to engage with scholarly communities there. He thus visited both the Royal Academy of Sciences in Stockholm and the naturalist Carl Linnaeus in Uppsala. In its protocol, the Academy interestingly presented Brander as 'a Swedish merchant, settled in London, who has been here in Stockholm for some time'. ${ }^{35}$ In the eyes of the secretary of the academy, Brander, born and raised in England and a British citizen, was hence still a 'Swedish merchant'. The comment not only underlines the fluid national identities of early modern Europe, but also hints at the importance for Brander of emphasizing his Swedish connections to audiences there. In a letter to

30 Hancock, op. cit. (9), p. 44.

31 A search through the digital repository Eighteenth-Century Books Online shows Spalding's name among the list of subscribers of e.g. Gilbert Burnet, Practical Sermons on Various Subjects, London: C. Ackers, 1747; Wyndham Beawes, Lex Mercatoria Rediviva: or, The Merchant's Directory: Being a Compleat Guide to All Men in Business, etc, London: John Moore, 1752. The same method shows that Brander was a subscriber to e.g. Joseph Ames, Typographical Antiquities: Being an Historical Account of Printing in England. With Some Memoirs of Our Antient Printers, London: W. Faden, 1749; Ben Jonson, The Works of Ben. Jonson. In Seven Volumes, London: D. Midwinter, 1756; Andrew Coltee Ducarel, A Series of Above Two Hundred Anglo-Gallic, or Norman and Aquitain Coins of the Antient Kings of England, London: E. Withers, 1757.

32 'Minutes of the Soc. of Antiquarians', 1748, vol. 5, Library of the Society of Antiquarians, London; 'Election records of Gustavus Brander', 1754, EC/1753/14, the Royal Society.

33 Albert Edward Musson and Eric Robinson, Science and Technology in the Industrial Revolution, Manchester: Manchester University Press, 1969, p. 127.

34 Thompson Cooper and D.G.C. Allan, 'Brander, Gustavus (1719/20-1787)', in Oxford Dictionary of National Biography (23 September 2008), at https://doi.org/10.1093/ref:odnb/3259, last accessed 25 May 2020.

35 'Vetenskapsakademiens protokoll, 1742-1751', Center for History of Science, Royal Swedish Academy of Sciences, Stockholm (KVA), p. 375, my translation. 
Abraham Bäck of 23 November 1751, Carl Linnaeus also wrote about Brander's time in Sweden. The Swedish naturalist thanked Bäck for introducing him to 'the polite Brandel [sic] from London' and he mentioned that they had met ' 2 or 3 times' during Brander's visit. Moreover, he described how Brander was 'curious, especially of petrifications [i.e. fossils]'. ${ }^{36}$ While in Stockholm, Brander thus seems to have sought to convince important commercial and scholarly contacts there that he was a loyal Swedish subject. One way of accomplishing this feat was to befriend Linnaeus, a prominent part of both Swedish science and the transnational Republic of Letters.

Brander's visit to Sweden underscores two aspects of how merchants such as Brander and Spalding related to the cultures of public science in the region around the Baltic and North Seas. The protocol from the Royal Swedish Academy of Sciences points to how these transnational merchants were identified in diverse ways by different cultures. Were we only to relate them to one context, we would fail to see how the perceptions of these actors shifted as they moved through the diverse cultures of the region. Therefore it is problematic to analyse actors such as these in a singular national context, in relation to a particular scientific discipline, or even strictly as either scholars or merchants. Moreover, when put side by side, there are striking similarities between how Brander acted in Stockholm and in his London life. At both places, he simultaneously maintained commercial and scholarly networks. For a wealthy and well-connected man like Brander, the role of a scholarly curious merchant was thus viable and encouraged in the genteel cultures of both London and Stockholm. As we will see in the following, their ability to act in both English and Swedish contexts, together with their capacity to offer scholars a logistical infrastructure, made it possible for men such as Spalding and Brander to partake in scholarly correspondence in several ways.

\section{Managing the flow of things in the Republic of Letters}

In Anglo-Swedish scholarly correspondence of the eighteenth century, one finds records of the shipping of letters, books and other objects, as well as the financial details of these exchanges. These letters moreover contain mentions of the logistical work underlying foreign scholarly tours. Still, these aspects of transnational scholarly exchange, consisting of scattered comments in various letters found in diverse archives, have attracted little attention from historians. Thanks to the numerous scholarly letters published over the last decades, both in digital form and in books, it is possible to piece together mentions of these mercantile practices into a larger picture. Here, I focus on three letter collections where Spalding and Brander are reccurring actors: primarily Linnaeus's correspondence, but also Spalding and Brander's own correspondence with the Swedish astronomer Per Wargentin, and the correspondence of the language scholar Edward Lye. ${ }^{37}$ While Spalding and Brander are mentioned in other letter

36 Carl Linnaeus to Abraham Bäck, 23 November 1751, Ms Linnébrev (KVA), my translation.

37 Reproductions of the letters to and from Linnaeus are collected in the digital repository Alvin, at www. alvin-portal.org. Edward Lye's letters are published in Margaret Clunies Ross and Amanda J. Collins (eds.), The Correspondence of Edward Lye, Toronto: Pontifical Institute of Mediaeval Studies, 2004. Of all these letter collections, Wargentin's is the only one that has not been transcribed or published. Wargentin's letters 
collections, these three are the scholarly collections that contain the highest number of letters either written by or addressed to Spalding and Brander, or where they were mentioned. The collections thus provide a good overview of how the two merchants acted as brokers and facilitators in three disparate fields of eighteenth-century scholarly knowledge. In these letters, one can discern roughly three ways in which Spalding and Brander interacted with contemporary scholars. First, they provided shipping services to both English and Swedish scholarly communities and discussed these services in their letters. Second, they maintained a financial infrastructure for scholarly correspondents and travellers. Third, they also engaged in the learned conversations themselves. The way these three roles overlapped emphasizes the fact that Spalding and Brander did not merely see a business opportunity in providing their services to the republic. The two merchants were themselves an integrated part of the scholarly world.

On 12 July 1754, three years after his visit to Sweden, Brander sent a letter to Linnaeus. 'The Civilities you did me when in Sweden', he wrote, 'have made too lasting an Impression on me to be soon forgotten'. In his letter, Brander explicitly offered his services to Linnaeus. He professed that he was 'always on the watch to procure you something curious in your way.' Brander had asked 'a worthy friend' of his, the naturalist Richard Werner, to 'open a correspondence with [Linnaeus], by sending [him] a few Curious Seeds', which he wished him luck in raising. Moreover, he offered Linnaeus his and Werner's help in providing any plant 'that is in his or my power' to obtain. In return, Brander pointed out that his 'study [was] in The Mineral Kingdom', and if Linnaeus could 'spare any thing curious therein, [he would] be glad to be remembered' by him. Finally, Brander told Linnaeus that if he wished to communicate any findings to the Royal Society, he should do so through him and that he would make sure that 'proper honour shall be done to the Communications of so illustrious an Honorary Member'. ${ }^{38}$

What is most striking about Brander's letter to Linnaeus is perhaps how typical it is. It followed what historians have identified as the standard protocol of scholarly exchange, where the correspondents exchanged, for example, seeds, minerals and new contacts as a way of extending mutual favours to each other. In his letter, Brander thus comes forth as an up-and-coming mineralogist who used his connection with the famous Swedish naturalist to position himself in English networks of natural history. The only sign of Brander's commercial contacts, and his ability to provide logistical services, is a short section where Brander points out that his 'friends at Stockholm [were] Appelroot \& Spalding, ${ }^{39}$

reside at the Centre for History of Science at the Royal Swedish Academy of Sciences (KVA). All in all, there exist forty-two letters that are written by or addressed to, or that mention, Spalding and/or Brander in these collections, dated 1742-1768. The letters used here were written in English, Latin and Swedish. The translations of Lye's letters are made by the editors of the edited volume. My own translations are marked in the footnotes.

38 Gustavus Brander to Carl Linnaeus, 12 July 1754, II, 149-150, Linnaean Society, London (Linn. Soc.). Brander wrote this letter in English and the quotes from this letter are thus in the original.

39 Brander to Linnaeus, op. cit. (38). 
Appelroot and Spalding was a trading house in Stockholm, consisting of Carl Appelroot and Karl Jacob Spalding (1702-1772), which mainly was involved in textile import. Karl Jacob was an older brother of Abraham Spalding, and Appelroot and Spalding was thus a part of Spalding and Brander's family network. The two pairs of merchants collaborated closely: when Appelroot and Spalding went bankrupt in 1776, Abraham Spalding was the largest creditor outside Stockholm. In addition to the debt to Abraham Spalding himself, Appelroot and Spalding also owed a large debt to Spalding and Brander. ${ }^{40}$ This debt structure tells both of the importance of transnational families in the eighteenth-century trade over the North Sea and the Baltic Sea, and of the fact that the suppliers in Stockholm were important to Spalding and Brander. These contacts were, however, also a resource in the Republic of Letters. Brander's choice to present his Stockholm business partners to Linnaeus, rather than, for example, naming other scholars he had befriended in the Swedish capital, was certainly no coincidence. By mentioning Appelroot and Spalding, Brander made a not very subtle hint that he could offer a fully developed logistical infrastructure, bridging Stockholm and London, to the Swedish naturalist.

Before the modern post, transnational exchange depended on improvised connections and the nurturing of personal relationships. While a European postal infrastructure developed over the $1700 \mathrm{~s}$, and private messengers thus gradually came to play a lesser role than in previous centuries, the regular mail was still expensive, and especially so for long-distance communication. Correspondents therefore continuously needed to evaluate how and what they needed to communicate and to weigh their needs to communicate against its costs on a case-by-case basis. ${ }^{41}$ Sometimes these deliberations were even explicit in letters. When writing to Linnaeus after just arriving in London on 30 February 1748, the naturalist Pehr Kalm discussed ways of communicating. He noted that he had received some letters from Linnaeus while in Norway, which he had answered. However, he was concerned that he had found no returning letters in London, neither at the post nor at the home of Abraham Spalding, whom he lived with. He thus first asked Linnaeus to send him letters in an additional envelope addressed to Spalding. Then he changed his mind, mid-sentence:

no, when I stop to think of it, then the envelope will cost as much as the letter itself when I collect it; therefore it is best if they [the letters] are sent directly to me; I will ask Mr. Spalding to make sure that they are always collected by him, and sent to me; but they have to be written and folded so that they have no envelope, but instead the address should be written on the same paper as the letter; Otherwise, as was said before, I must pay a shilling for the envelope alone. ${ }^{42}$

As indicated by Kalm's letter, the correspondences of eighteenth-century scholars were not simple linear point-to-point connections through which scholars could share information and establish relationships. To communicate, Kalm was required to solve several practical issues. As seen from the extract, he needed to take the very materiality

40 Nyberg, op. cit. (10), pp. 11-12.

41 For scholarly tactics to avoid postal costs see Goldgar, op. cit. (2), p. 17.

42 Pehr Kalm to Carl Linnaeus, 20 February 1748, vol. VIII, p. 15, Linn. Soc., my translation. 
of the letters into account, in order to communicate efficiently over the North Sea and the Baltic Sea and to reduce costs. However, scholars also often needed to establish relationships with the actors who offered routes through which objects would move. Such considerations were even more important when transporting heavier objects such as books or scientific instruments. In those cases, the regular post was too expensive to be an alternative, and instead scholars generally used cheaper messengers. For transporting such objects, merchants such as Spalding and Brander thus played yet another important role. ${ }^{43}$

A letter from Brander to Linnaeus of 11 February 1756 provides an example of how books moved over the North Sea and the Baltic Sea. Patrick Browne had sent three copies of his book The Civil and Natural History of Jamaica to Stockholm through 'Mr. Ray', a bookseller in Amsterdam, and one of these books was meant for Linnaeus. ${ }^{44}$ By way of the clergyman of the Swedish Lutheran Church in London Carl Noring, Brander, however, heard that these books had never made it to their destination, and he had, therefore, sent another copy with the ship Maria Sophia, a Swedish merchant ship sailed by the captain Johan Hindrich Gatthin. Brander informed Linnaeus that the cost of the book could be reimbursed through Appelroot and Spalding. ${ }^{45}$ However, according to a letter of 19 October 1756 from Linnaeus to Browne, despite all these efforts to get The Civil and Natural History of Jamaica to Stockholm and Uppsala, Linnaeus received neither the books from Browne nor the copy from Brander. Instead, he had found out that 'an Englishman residing at Stockholm had got it; I intreated him to lend it me for a fortnight, and obtained [possession] of [it] ${ }^{46}$ These failed attempts to transport Browne's book underline the potential instability of the shipping infrastructure bridging the Baltic Sea and the North Sea. Some objects were not successfully delivered until correspondents had tried to send them over multiple routes.

When logistics broke down, which it often did, practical matters took centre stage in scholarly letters. In 1757, Spalding and Brander wrote a letter to the astronomer Pehr Wargentin at the Royal Swedish Academy of Sciences. Wargentin had not received a book about 'salt manufacture' that he had requested, and he had consequently asked for details about its itinerary. Spalding and Brander confessed that they had 'completely forgotten what shipper we used to send the package'. 'Probably', they continued, 'it was with Capt. Törnlund as he is our package deliverer when the press produces something here'. The two merchants, however, argued that they seldom noted who carried their packages, as they believed 'that it was no more necessary for the customs officers to

43 On the roles of messengers and the regular post in eighteenth-century Europe see Caplan, op. cit. (5), pp. 51-52.

44 Patrick Browne to Carl Linnaeus, 11 March 1756, vol. II, pp. 192-193, Linn. Soc.; Patrick Browne, The Civil and Natural History of Jamaica: In Three Parts, London: T. Osborne, and J. Shipton, in Gray's-Inn, 1756.

45 Gustavus Brander to Carl Linnaeus, 2 November 1756, II, 151-152, 151a, Linn. Soc., my translation (whereas Brander's first letter to Linnaeus was written in English, his second letter was in Swedish). The following year, the Maria Sophia was seized by the British authorities, suspected of contraband, and the captain's full name can be found in the papers of the following claims and attestations: 'Captured ship: Maria Sophia (master Johan Hindrich Giathe or Johan Hindrich Gatthe)', 1757, HCA 32/218/22, The National Archives, Kew.

46 Carl Linnaeus to Patrick Browne, 19 October 1756, vol. IX, pp. 206a-b, Linn. Soc. Browne had written to Linnaeus in Latin; Linnaeus responded in English. 
know the name of the shipper of some printed or written papers than the postrider's name concerns the postmaster'. ${ }^{47}$

Spalding and Brander's letter to Wargentin might compel us to compare the social order of scholarly correspondence with similar hierarchies found in early modern experimental philosophy. Historians of science of recent decades have shown how early modern experimentalists routinely obscured the work of servants and technicians in order to present scientific practice as a clean and cerebral enterprise carried out by gentlemen. ${ }^{48}$ One should not, however, draw this parallel too far. While there certainly did exist norms in the letter correspondence of obscuring, for example, the work of the many sailors and servants involved in transnational communication, there is little to suggest that merchants and ships' captains were invisible or marginalized in the same way. In fact, Spalding and Brander's confession of having forgotten who carried the letter was an anomaly, when viewed in relation to their other letters to Wargentin, as well as in comparison to other Anglo-Swedish scholarly correspondence. For example, in a letter written less than three months earlier, on 28 May 1757, the two merchants told Wargentin that the naturalist Kalm was now home from North America. They took care to note that Kalm's servant was on his way home too and that he was on the ship Assurance of the sea captain Nils Törnlund, together with a collection of seeds and plants. ${ }^{49}$ Spalding and Brander's letters to Wargentin generally contained many details about shipped goods. In an earlier letter of 1751, they discussed the contents of a box that they had shipped to Stockholm, which contained, among other things, Maclaurin's A Treatise of Algebra, the two volumes of his A Treatise of Fluxions, Simpson's The Doctrine and Application of Fluxions and some glass prisms. They also informed Wargentin that the box was shipped with Captain Törnlund. ${ }^{50}$ In 1752, the merchants yet again added a list of goods in a letter to the Swedish astronomer (including books such as Gardiner's Tables of Logarithms and Baker's The Microscope Made Easy, as well as a lens, Short's reflecting telescope and a simple microscope), and informed Wargentin that everything was in a box, which yet again was carried by the Assurance. ${ }^{51}$ In fact, in the five letters signed by both Spalding and Brander found in Wargentin's archive, four mention Nils Törnlund. The fifth instead mentions another sea captain, Johan J. Fischer. The names of these two ships' captains and their ships are also found in Linnaeus's correspondence with English scholars. ${ }^{52}$

47 Abraham Spalding, Gustavus Brander to Pehr Wargentin, 23 August 1757, Wargentin's archive, KVA, my translation.

48 Steven Shapin, 'The invisible technician', American Scientist (1989) 77(6), pp. 554-563. For an overview of the field following Shapin's lead see Iwan Rhys Morus, 'Invisible technicians, instrument-makers and artisans', in Bernard Lightman (ed.), A Companion to the History of Science, Hoboken: John Wiley \& Sons, 2016, pp. 138-152.

49 Abraham Spalding, Gustavus Brander to Pehr Wargentin, 28 May 1757, Wargentin's archive, KVA, my translation.

50 Abraham Spalding, Gustavus Brander to Pehr Wargentin, 23 April 1751, Wargentin's archive, KVA, my translation.

51 Abraham Spalding, Gustavus Brander to Pehr Wargentin, 24 October 1752, Wargentin's archive, KVA, my translation.

52 Mentions of Captain Törnlund can be found in three letters to Linnaeus from the same period: Kalm to Linnaeus, op. cit. (42); Daniel Solander to Carl Linnaeus, 11 July 1760, vol. XIV, pp. 128-130, Linn. Soc.; Daniel Solander to Carl Linnaeus, 21 July 1760, vol. XIV, pp. 131-132, Linn. Soc. Mentions of Fischer are 
The pattern in all letters studied here is thus that the shipper's name was not at all unimportant to the two merchants or to the scholars with whom they communicated. Instead, merchants and scholars alike meticulously noted who carried which boxes, on what ship they were carried and what they contained. Unsurprisingly, when using the fragile shipping infrastructure bridging the Baltic Sea and the North Sea, such information could be crucial when tracking down a package that had gone missing. The fact that Spalding and Brander routinely used the same ships' captains, even though the shipping routes between England and Sweden were trafficked by numerous vessels, again highlights the role of long-lasting personal relationships with heterogeneous categories of actors in the early modern Republic of Letters. By knowing the name of the shipper, or even better by befriending the ship's captain, merchants and scholars alike gained a transparent means of making information, things and people move over the region, while they also attained a greater degree of accountability should the logistics break down. ${ }^{53}$

Again, the need for reliable shipments gave Spalding and Brander, with their regional mercantile contacts, a special position in the scholarly networks of the region. Through their trading routes, they could offer itineraries constituted by trusted shippers and business partners. Using these routes, scientific books and instruments, as well as travelling scholars themselves, could move over the North Sea and the Baltic Sea. Merchants such as Spalding and Brander could thus offer a shipping infrastructure based on personal relationships between scholars, merchants and shippers that was often more cost-effective and more transparent than the official post.

\section{Financing circulation of knowledge}

The shipping services which merchants such as Spalding and Brander offered scholars were intertwined with a financial infrastructure for long-distance transactions. By the end of the 1700s, international trade had expanded in volume. Nevertheless, modern financial inventions such as correspondent banks-i.e. banks providing services for other banks on a foreign market - were still uncommon, and international legal enforcement was weak. Instead, early modern European trade was made possible through the circulation of bills of exchange, documents 'from a merchant (the issuer) to his agent abroad (the payer), commanding him to make payment in a different location on his behalf to a third party (the beneficiary) at a set date in the future'. For this system to work, merchants to a great degree depended on a network of trusted actors, generally in the form of transnational family relationships. ${ }^{54}$ Thus Appelroot and Spalding

found in four letters to Linnaeus from the 1750s and 1760s: Thomas Pennant to Carl Linnaeus, 3 June 1756, vol. XI, pp. 414-415, Linn. Soc.; Pehr af Bjerkén to Carl Linnaeus, 14 June 1758, vol. II, pp. 15-16, Linn. Soc.; Peter Collinson to Carl Linnaeus, 22 August 1758, vol. XVII, p. 38, Linn. Soc.; James Gordon to Carl Linnaeus, 16 August 1761, vol. V, pp. 77-78, Linn. Soc.

53 A great number of ships' captains sailed between London and Stockholm during the period, as seen in the Sound Toll online database (www.soundtoll.nl). Obviously, this list does not include vessels that trafficked London and Gothenburg, which did not pass through the sound.

54 Veronica Aoki Santarosa, 'Financing long-distance trade: the joint liability rule and bills of exchange in eighteenth-century France', Journal of Economic History (2015) 75(3), pp. 690-719, 691; See also Kurt 
often constituted the financial counterpart in Stockholm, through which scholars could pay for goods purchased by Spalding and Brander in London. At other times, the two London merchants asked their recipients to provide payment to Johan Clason, a previous close business partner of Spalding, who had left London and returned to Stockholm in the 1740s. Often shipping and financial services went hand in hand. When they helped with the shipments of books, instruments and naturalia, Spalding and Brander also provided means for the recipients to pay for the goods through this system of bills of exchange.

Through their financial counterparties, Spalding and Brander also facilitated the transactions of travelling scholars. As was the case for the practical issues of shipping discussed above, money matters are hardly invisible in the letters of travelling scholars. For example, like many similar study tours, the naturalist Daniel Solander's voyage to London was financed through a stipend. To access these funds, he continuously corresponded with his patron and former professor Carl Linnaeus. On 19 December 1760, he thanked Linnaeus 'for his trouble with the transfer of the stipend, which correctly has arrived at Mr. Spalding and Brander'. However, Solander complained, 'at the moment there is a terrible exchange rate on small sums, every pound costs 69 [Swedish] copper dalers'. ${ }^{55}$ When Solander asked about his stipend, he often mentioned that it should be transferred in 'the previous way'. ${ }^{56}$ Once again, Appelroot and Spalding in Stockholm and Spalding and Brander in London were central to these transnational transactions. On 1 January 1762, Linnaeus wrote to Solander, 'last Tuesday, I sent with Magister Neander the 3000 copper dalers that were withdrawn for year 2 of your stipend; to be sent with Apelroth and Spalding in the same way as previously'. ${ }^{57}$ A letter from Appelroot and Spalding themselves to Linnaeus of 10 November 1760 provides even more detail about these financial practices. There, the merchants pointed out how they had received the sum of 1,300 copper dalers from Linnaeus and that they had 'Credited Mr. Spalding \& Brander in London, and would inform them thereof with tomorrow's post'. In that way, by acting as trusted payers for the issuers in Sweden, the merchants in London could provide Solander (the beneficiary) with the funds necessary for his travels. ${ }^{58}$

These mentions of money matters again provide a contrast to earlier studies, discussed above, that have characterized the Republic of Letters as a gift economy. By using the system of bills of exchange, Spalding and Brander could thus help scholars with a range of transnational transactions that made the circulation of knowledge possible. More concretely, practices such as the exchange of letters and books, and the voyages

Samuelsson, 'International payments and credit movements by the Swedish merchant-houses, 1730-1815', Scandinavian Economic History Review (1955) 3(2), pp. 163-202, 165.

55 Daniel Solander to Carl Linnaeus, 19 December 1760, XIV, 135, Linn. Soc., my translation.

56 See e.g. Daniel Solander to Carl Linnaeus, 16 November 1761, XIV, 140-141, 152, Linn. Soc., my translation.

57 Carl Linnaeus to Daniel Solander, 1 January 1762, Additional Ms 32439, 2-3v, British Library, my translation.

58 Appelroot and Spalding to Carl Linnaeus, 10 November 1760, vol. I, pp. 157-159, Linn. Soc., my translation. 
of travelling scholars throughout Europe or globally, all depended on the ability to circulate such bills. Shipments and long-distance financing depended on each other to such a degree that they can be considered the two main parts of a logistical infrastructure. Spalding and Brander's actions thus hint at understudied commercial aspects of early modern scholarly networks, and especially how emerging systems of long-distance financing facilitated early modern knowledge circulation.

When this monetary undercurrent was disrupted, it could also interrupt the transnational relationships of scholars. For example, the services of Spalding and Brander were also used in exchanges between contemporary language scholars. After receiving three copies of a new edition of Ulphilas from Edward Lye, Carl Jesper Benzelius replied on 9 November 1752 that the previously mentioned merchant in Stockholm Clason 'had promised to send the money, so I assume that it can be obtained from Mr. Spalding's office in London'. ${ }^{59}$ Yet things did not progress smoothly with the payment. On 24 May 1754, after making excuses for the delay in his response, Lye answered Benzelius that he was 'glad to hear, that the three last copies came safe to hand'. Still, 'Mr. Spalding hath had no orders from Mr. Clason to pay me for two of them. You wou'd oblige me by putting Mr. Clason in mind of the orders You had given him' ${ }^{60}$ On 7 October, Benzelius replied, writing that it hurt him that Clason had handled his role as an issuer so poorly. Benzelius even felt obligated to send his copy of Clason's receipt to Lye in an attempt to exonerate himself, while giving his assurance that he had made arrangements with the Swedish merchant for prompt payments through Spalding. ${ }^{61}$ The non-functional relationship between Clason (the issuer) and Spalding (the payer) had clearly affected Benzelius's relationship with Lye. The episode thus highlights how scholarly relationships depended on the smooth operation of an underlying financial infrastructure.

For travelling scholars, breakdowns in the mercantile relationships that made bills of exchange possible could have much more dramatic consequences. On 10 December 1749, Kalm, now in Philadelphia, wrote a letter to Linnaeus in haste. After pointing out that he only had an hour and a half to write both this letter and another one to Spalding, before a ship would leave for London, Kalm started to account for his financial difficulties of late. He wished to remain in America for one more year than initially planned, but his Swedish scholarship did not cover this extended stay. Spalding, in London, had not received new instructions from the financiers of the voyage in Stockholm, and consequently, he had informed the travelling naturalist that he was reluctant to forward new money. To cover his costs, Kalm instead had asked Spalding for a personal loan of 60 pounds. Spalding granted this loan and issued a bill to a commercial contact of his in Philadelphia, the merchant Peter Kock, who would make the money available to Kalm on the other side of the Atlantic. ${ }^{62}$

59 Clunies Ross and Collins, op. cit. (37), p. 213.

60 Clunies Ross and Collins, op. cit. (37), p. 217.

61 Clunies Ross and Collins, op. cit. (37), p. 220.

62 Pehr Kalm to Carl Linnaeus, 10 December 1749, VIII, 22-23, Linn. Soc., my translation. 
However, Kalm's financial troubles did not end there. Before he received his money, Kock died from a 'deadly and short illness'. The heirs of the Philadelphia merchant had therefore denied Kalm his money, as they 'did not know what [Kock] had already given him, and on what foot'. The personal relationship between the two merchants Spalding and Kock was the link that made Spalding's bill, and in turn Kalm's loan, meaningful in America. The sudden death of Kock thus meant that Kalm once again stood without usable funds. Luckily, Kalm's letter ended on a lighter note. Shortly after returning to Philadelphia, he had received a new letter from Linnaeus, which informed him that the Royal Academy of Sciences in Stockholm had granted him support for his extended stay in America. Kalm hence sent a copy of Linnaeus's letter to Spalding, so that he could issue a new bill to some other Philadelphia merchant and end Kalm's financial troubles. ${ }^{63}$

These two examples of how the financial infrastructure broke down underline some of the many ways in which Spalding and Brander facilitated the transnational circulation of books and instruments, as well as the voyages of scholars, by managing the flow of money. Also, the examples again bring to the fore logistical aspects of the Republic of Letters that have been understudied. If, in Goldgar's words, the Republic of Letters was located not in specific institutions but 'in the relations among its members', then what made these scholarly relations possible? ${ }^{64}$ In the letters discussed here, scholarly relationships clearly intersected with the mercantile relationships that were part of the system of bills of exchange. Studying these scholarly and mercantile relationships together thus makes it possible to understand the relationships that made transnational exchange possible in new ways. Moreover, the letters show the limits of the extent to which Spalding and Brander were willing to participate in scholarly communities. Whereas they were ready to give scholars access to their mercantile infrastructure, they did not act as philanthropists in relation to the scholarly republic. Instead, their financial services were governed both by the norms of mutual obligations, prevalent in the early modern Republic of Letters, and by other sets of mercantile norms and rules. A bill of exchange was only as good as the credibility of the merchants who were its issuer and payer (in both an economic and a broader social sense). To maintain this credibility, the merchants constantly assessed the risk of entering into financial agreements, and made sure that their obligations were fully financed.

\section{Conclusions: the practices of making knowledge move}

In this paper, the two merchants Spalding and Brander have served as a lens for examining a little-studied aspect of eighteenth-century scholarly communication. While the modern concept of logistics would have been foreign to these merchants, as an analytic concept it has helped us identify several mercantile practices, related to long-distance shipping and financing, which were pivotal for circulating early modern scholarly knowledge. So why did Spalding and Brander provide such logistical services to

63 Kalm to Linnaeus, op. cit. (42), my translation.

64 Quote from Goldgar, op. cit. (2), p. 6. 
British and Swedish scholars? An important explanation, as seen from the discussion above, is that by doing so they could carve out a place for themselves within transnational scholarly communities. Spalding and Brander were merchants who lived in London, one of the foremost commercial hubs of eighteenth-century Europe, but who mainly traded with Sweden, a fallen Baltic empire of dwindling importance. While their trade evidently was economically profitable, it could not have been particularly prestigious in English genteel culture. For them, the asymmetry of Sweden's relatively central role in many scholarly fields, as compared to its lesser economic and geopolitical role, was an opportunity to offset this lack of prestige. Swedish nyttiga wettenskaper and British useful knowledge were commodities that bore many cultural similarities. Due to the prestige of, for example, natural history, mathematics and chemistry in the genteel cultures of both Britain and Sweden, managing the physical flow of information, objects and people of these fields could provide status in both countries. Thus, by participating in scholarly exchange, Spalding and Brander became more than mere ironmongers to audiences in London, and in the process they could reflect themselves in the light of prestigious foreign contacts such as Carl Linnaeus and Pehr Wargentin. Likewise, in Stockholm, the two merchants could present themselves as Swedish merchants with important foreign contacts and who aided fields of knowledge seen as an underpinning of Swedish genteel culture. As logisticians in the Republic of Letters, Spalding and Brander could thus turn their already available commercial relationships into generators of cultural status valid in both London and Stockholm.

As seen from the letters discussed here, the merchants' services to the scholarly world came in many different forms: they offered means of simplifying and making communication less costly, they facilitated regional transport of heavier goods such as books or even scientific instruments, and they made available an infrastructure for long-distance financing necessary for making scholarly knowledge move. Together, these services can be considered a logistical infrastructure for the flow of information, people and things. In turn, this infrastructure was pivotal to the transnational exchanges that formed the scholarly relationships studied here. The clearest example is perhaps the episode of Kalm's travel stipend. The fact that bills of exchange needed to travel over the Atlantic to Spalding in London, and then back again to Philadelphia, before local merchants made money available to the travelling naturalist underscores the power that existed in mercantile relationships, and the way circulation of scholarly knowledge depended on them. While we should not infer too broad conclusions from the limited cases studied here, it is difficult to see how the resources required for transnational communication and collaboration would have been readily available, if scholarly communities had not relied on transnational brokers such as merchants. Without ships, knowledge could not cross oceans. And without a system of long-distance financing, letters, books or scholarly travellers could not circulate across disparate geographies. By including merchants with logistical expertise among their peers, scholars could gain access to the important resources and expertise of merchants, sea captains and bankers. These categories of actors could manage the flows of money, objects and people in ways that most scholars could not dream of accomplishing on their own. 
By offering scholars access to a set of mercantile practices, Spalding and Brander also became increasingly integrated into scholarly communities. But the two merchants studied here were hardly the only merchants engaged in scholarly activities. Contemporary British naturalists such as Peter Collinson and John Ellis, who were friends of Spalding and Brander, also made their living as merchants. Similarly, men such as Jonas Alströmer - an associate of Brander's father in London at the dawn of the 1700s - were key figures in the institutionalization of science in eighteenth-century Sweden. Consequently, if we want to understand the relationships that both constituted and transformed the Republic of Letters, we should include other modes of transnational exchange in our analysis of the scholarly world. In the process, such wider studies - that take logistical practicalities into account - could give new perspectives on why so-called useful knowledge overtook other forms of curious pursuit by the middle of the eighteenth century.

The cases presented here thus indicate the need for wider studies of the practical infrastructure of scholarly exchange. Such studies could provide more information on the circulation of early modern scholarly knowledge in practice, while they might also revise our view of the Republic of Letters from a community of relatively homogeneous scholars, to one that involved networks of diverse actors with various sets of expertise. 